International Journal of English Literature and Social Sciences
Vol-6, Issue-5; Sep-Oct, 2021

Peer-Reviewed Journal

\title{
Educational Practice at the Prison System as a Guarantee of the Right to Education for Convicts: Possibilities and Limits
}

\author{
Ênnio Santos Barros ${ }^{1}$, Leidiane Sousa Lima Fernandes², Clara Weinna Moura Dantas 3 , \\ Ilma Maria de Oliveira Silva ${ }^{4}$, Carlos André Sousa Dublant ${ }^{5}$, Francisca Morais da \\ Silveira ${ }^{6}$
}

\footnotetext{
1,2,3 Master's student at the Postgraduate Program of Teacher Training in Educational Practices at the Universidade Federal do Maranhão. ${ }^{4}$ Doctor in History from the Universidade do Vale do Rio dos Sinos - UNISINOS. Master in Education from the Federal University of Maranhão - UFMA.

${ }^{5}$ Doctor in Education from the Federal Universidade do Rio Grande do Norte.

${ }^{6}$ Doctorate and Master's Degree in Psychology (Behavior Theory and Research) from the Universidade Federal do Pará.
}

Received: 10 Aug 2021; Received in revised form: 02 Sep 2021; Accepted: 11 Sep 2021; Available online: 16 Sep 2021 C2021 The Author(s). Published by Infogain Publication. This is an open access article under the CC BY license (https://creativecommons.org/licenses/by/4.0/).

\begin{abstract}
Our study aims to reflect on the existing possibilities and limits to pedagogical practices developed in the prison space. Education is a social right, enacted and legally guaranteed in international and national provisions. These provisions foresee the offer of an education of a popular nature, as principles of human emancipation and autonomy under specific pedagogical practices for people deprived of their liberty. Under this prism, punishing and rehabilitating are the main objectives of the prison system, but the imperatives of the punishment end up overlapping with education and this dual goal that is expected of incarceration denounces contradictions in the organization of prisons. In this study, we used qualitative research under the perspective of Bogdan and Biklen (1994); bibliographical revision involved works already published during the latest five years in digital platforms of databases for scientifical works that were related to the descriptors (education practices; liberty deprived; difficulties; possibilities), which were combined between each other via Boolean operator "AND". We observed the right to education for liberty deprived persons in several legal provisions; however, the effectivity of the existing pedagogical practices presents possibilities and limitations regarding the disinterest of society that has an influential look at prison schools, and also due to the lack of autonomy of teachers in prison schools, lack of school support, the non-recognition of the importance of education by other professionals, as well as the precariousness of the physical structure.
\end{abstract}

Keywords - Pedagogical Practices, Right to education, Liberty deprivation.

\section{INTRODUCTION}

In a country where the prison population has only been growing, due to problems of social, economic and educational orders, prison unities are becoming more and more crowded, and many inmates end up receiving degrading treatment.
França, Félix and Feitosa (2020) affirmed that education has been a path of social change and transformation. For these authors, liberty deprived people (LDP) are undergoing the fulfilment of their sentence; consequently, their right to education must be ensured, since national and international legal provisions treat education as a social right, irrefutable to the imprisonment situation. 
At an international level, we highlight the Universal Declaration of Human Rights, which reflects on the dignity of the human person in any social space and promulgates the universalization of the primary education. Accordingly, both the Federal Constitution of 1988 and the Law of Guidelines and Bases for National Education LDBEN $^{1}$ No. 9,394/96 reinforce the State's obligation to universalize primary education.

A relevant aspect preconized by the LDBEN is the integration to the Brazilian education system of the Youth and Adult Education $\left(\mathrm{EJA}^{2}\right)$ as a mandatory and noncompensatory part for Brazilians excluded from childhood educational processes. Therefore, an educational concept that includes educational practice, methodology and the public involved is relevant.

Within an educational perspective for the liberty deprived person, the right to education is foreseen in the Law of Criminal Enforcement $\left(\mathrm{LEP}^{3}\right)$ No. 7,210, from July $11^{\text {th }}$ of 1984 and in Resolution No. 03 of March $11^{\text {th }}$ of 2011, that institute the National Guidelines for the offer of education in the prison facilities. These devices provide for the offer of an education of a popular nature, as principles of human emancipation and autonomy under specific pedagogical and methodological practices for people deprived of liberty.

Faced with legal provisions that guarantee the right to education as a social right, it is important to reflect on the perspective of identifying the main points that limit the proposals and pedagogical activities developed in the prison space, guided by the prism of a Popular Education.

Torres, José and Santos (2021) affirmed that the educational activities developed in liberty deprivation spaces, be them formal or informal, take place in a distinct way from school spaces, in view of the hostility that belongs and is marked to the "penitentiary system" and the need for the State to institute disciplinary measures and/or institutional control, through rules that often do not ensure human valuation.

It is noteworthy that within the daily dynamics of prison institutions, LDP remain idle for a long time; it is in this aspect that work and educational activities contribute to the realization of the process of humanization of inmates, thus enabling them to be reintegrated into society. However, what we have seen is a prison context with structural and human resource deficiencies that make it

${ }^{1}$ LDBEN: from the Portuguese Lei de Diretrizes e Bases da Educação Nacional.

${ }^{2}$ EJA: from the Portuguese Educação de Jovens e Adultos.

${ }^{3}$ LEP: from the Portuguese Lei de Execução Penal. difficult to configure the possibilities in the provision of educational activities.

Schools that work behind bars welcome subjects who were removed from society and who had often studied regularly, so these spaces need to take on a differentiated character, in which subjects find meaning for their existence, even if deprived of freedom. It would be, then, a school that makes it possible to understand the temporality that this condition of deprivation imposes on human beings and, consequently, allows them to develop perspectives of life.

For this study, we used qualitative research from the perspective of Bogdan and Biklen (1994). The study was carried out through a literature review. Exploratory methodological procedures contribute to the survey of works already published in the previous five years on digital platforms in databases of scientific articles related to the subject of study presented.

The result of the literature review, considering the selected descriptors (Educational practices; Liberty deprived; Difficulties; Possibilities) were combined with each other by means of the Boolean Operator "AND".

As filters, a time frame from 2017 to 2021 was used, including only scientific articles in Portuguese, fully available in the aforementioned digital media. Duplicate contents, studies with tangential themes to the researched one, as well as congress or conference proceedings, were discarded.

From the total number of studies reached, an a priori selection was made by reading their titles. However, in a second moment, through the reading of the abstract and objectives, it was detected that a large part of the works did not fit the inclusion criteria, and some were not fully available for Downloads; thus, only 10 works were qualified for an analysis.

In this sense, this research initially presents the main laws that guarantee education for all people, in general, including people in situations of deprivation of liberty. The second point addressed the limits, perspectives and possibilities for developing educational practices in the most diverse prison environments. To conclude, the final considerations of the main impressions acquired after carrying out this study.

\section{LEGAL LANDMARKS: PROCLAMATION OF EDUCATION AS A RIGHT FOR CONVICTS}

Many are the norms, decrees and declarations that discuss education as a Universal Right. The intention of this session, therefore, is to provide a brief overview of the main legal frameworks that deal with education as a right and to correlate them with education for convicts. Thus, as 
an initial highlight, we have the Universal Declaration of Human Rights adopted and proclaimed by the United Nations in 1948, right after the barbaric episodes that marked the end of World War II. This declaration proposes universal presuppositions to guarantee the dignity of the human person, regardless of class, social, race, color and culture and, in its preamble, it reinforces that teaching and education promote the guarantee of rights and freedom. In its article 26, it highlights the role of education by declaring that,

1. Everyone has the right to education. Education shall be free, at least in the elementary and fundamental stages. Elementary education shall be compulsory. Technical and professional education shall be made generally available and higher education shall be equally accessible to all on the basis of merit.

2. Education shall be directed to the full development of the human personality and to the strengthening of respect for human rights and fundamental freedoms. It shall promote understanding, tolerance and friendship among all nations, racial or religious groups, and shall further the activities of the United Nations for the maintenance of peace.

3. Parents have a prior right to choose the kind of education that shall be given to their children.

Faced with such premises, it is important to highlight that it is the duty of the State to guarantee the offer for Basic Education. This achievement, according to Gadotti (2013), it is not limited only to the offer and opportunity of access, but the permanence and completion of this level of education, as well as the assumption of conditions to continue studies at other levels.

Concerning these propositions, the Brazilian Federal Constitution of 1988 guarantees fundamental rights, and even promotes the role of education in its article 205, when it says "education, the right of all and the duty of the State and the family, will be promoted and encouraged with the collaboration of society, aiming at the full development of the person, its preparation for the exercise of citizenship and their qualification for work" (BRASIL, 1988).

The Constitution, in line with international policies, provides for the guarantee of access to education and fosters the role and function of the State in promoting these rights. Therefore, "it is up to the State to take on the duty of providing conditions for the enjoyment of these rights, taking down the barriers that hinder the exercise of such rights" (CURY, 2013, p. 201). The democratic State established from 1988 onwards, proposes to guarantee fundamental social rights for the fulfillment of citizenship, with an emphasis on maintaining this commitment, with regard to the universalization of Elementary Education and its mandatory nature.

Thus, Basic Education, provided for in the Law of Guidelines and Bases for National Education No. $9,394 / 1996$, in its article 2, promulgates that Education is a duty of the family and the State in favor of human development, its preparation for citizenship and their qualification for work. Fostering the role of the State in ensuring the social right to education, Carneiro (2012) points out that the State should promote ways to make viable the right to education and the well-being of all.

Another factor highlighted by the author is the relationship with article 208 of the Constitution, which focuses on the provision of compulsory and free Elementary Education, through the guarantee for those who did not have access at their own age, treating it not only as a right that is legally guaranteed, but that "simultaneously imposes a duty that falls to it, and as a result of a legal imposition, compliance can be carried out by force of law" (CARNEIRO, 2012, p. 47). It is important to emphasize that inmates are deprived of the right to come and go, therefore other rights such as health and education are still legitimate and must be offered.

Within this perspective, education for liberty deprived peoples is understood as Youth and Adult Education EJA -, which is provided for in article 37 of the LDB, that states that this type of education is intended for those who did not have access or continuing basic education at the right age. For Gadotti and Romão (2011), the EJA, when composing the regular educational system of education, brings forth pedagogical and educational proposals consistent with the specificity of this audience.

Another legal regulation that provides for the guarantee of the right to education at the national level is the National Education Plan $\left(\mathrm{PNE}^{4}\right)$, Law 13,005 of 2014 , as it sets Educational Guidelines that must direct the action of the Union, States and Municipalities in favor of education

${ }^{4}$ PNE: from the Portuguese Plano Nacional de Educação. 
quality and democratic in access and permanence. Faced with such legal prerogatives, it is noteworthy the guarantee of education as a social and inviolable right for the population, necessary for the full development and exercise of citizenship, including those deprived of liberty.

Being specific in the legal prerogatives for guaranteeing the right to education in the context of people deprived of liberty, with an emphasis on the National Education Plan, we direct our eye to Goal 9, that dealt with EJA, but specifically its strategy 9.8 , described in way of

securing the offer for
education of youth and adults,
during the stages of
elementary education and high
school, to liberty deprived
peoples from all prison
complexes, ensuring specific
training for male and female
teachers and implementing
national guidelines on a
collaborative basis (BRASIL,
2014).

Thus, EJA, from the view of the convicts, is understood as a right and a duty of the State when it comes to elementary education. It must be education from the perspective of Gadotti and Romão (2001), as they argue that it should be guided by respect for common sense, and also by a theory present in popular practice, providing opportunities for the point of view of those involved.

In the rights discussed above, we also mention that the Law of Criminal Execution (LEP) No. 7,210 of July 11 of 1984, aims to implement the provisions of criminal sentence or decision, and provide conditions for the harmonious social integration of the convict and the inmate, being also consistent with the LDB, when it provides in its article 18 the obligation of the State to offer elementary education to inmates, in addition to incorporating a cross-reference feature where in every 12 hours of school attendance there is a reduction of 1 day of their sentences. This law also provides that the education offered may be linked to professionalizing aspects.

Another resolution deserving of notice is No. 03 of March 11 of 2011, as it institutes the National Guidelines for the offer of education at prisons. It even consolidates some of the claims and observations pointed out by the National Seminar for Education in Prisons: Meanings and Propositions, attached to this resolution. The resolution draws attention to the guarantee of the right to education in two aspects of article 3:

I- Attending to the axes agreed upon when the National Seminar for
Education in Prisons (2006) was held, namely: a) management, articulation and mobilization; b) training and valuing professionals involved in providing education in prison; and c) pedagogical aspects; [...]

IV - Be associated with actions to encourage reading and the implementation or recovery of libraries to serve the prison population and professionals working in penal establishments; and (BRASIL, 2011).

In item I, prison education is divided into three axes, fostered by the Seminar, where the axis of pedagogical aspects addresses the concern with an education that shapes subjects favoring the autonomy and emancipation of the individual from the educational process, from an educational perspective popular.

This axis also foresees the importance of elaborating a pedagogical proposal that comprehends knowledges, culture, sports and professionalization, considering the reality of each confinement space and the methodologies adopted. Still under this bias, another aspect pointed out is the relevance in the elaboration of a curriculum for education in prisons that considers the time and the subjects inserted in this context and in the confrontation of social reintegration.

In addition to a pedagogical proposal and a curriculum consistent with our reality, the valuation of the education professional who will carry out these elements must be based on the process of continuous training, considering the human condition of deprivation of liberty and the social conditionalities that manifest themselves in a process of social exclusion. There are, therefore, fundamental aspects to guaranteeing education as a social right, aiming at resocialization through the use of principles such as autonomy and emancipation inherent to a popular educational proposal.

\section{POSSIBILITIES AND LIMITS FOR EDUCATIONAL PRACTICES IN THE PRISON CONTEXT}

For the past few decades, the debate on education within the prison system in Brazil has been strongly linked to the social role of schools, under a Popular Education bias and in view of avoiding repeat offenses. However, faced with a prison system that is critical from its very creation, these spaces are stigmatized and as we know or have knowledge 
of, surrounded by large walls and bars. In short: gray, dark places, covered with fear and terror.

Given the dichotomous context that concerns the prison system, but specifically the educational one, it is important to establish the possibilities and limits that this situation presents, given the established educational practices, so that they can promote the guarantee of the right to education for liberty deprived people.

Thus, regarding the possibilities in a chaotic scenario, Florêncio and Costa (2021) state that education, a legally guaranteed right, promoted in prison, can be an alternative for the construction and/or rescue of self-esteem, of reflective capacity, as well as the devolution of subjects' basic rights, such as the feeling of social belonging.

Currently in Brazil, only about $10 \%$ of the prison population participates in some sort of educational activity. This information on education in prison can be confirmed by the reports of the National Penitentiary Department $\left(D_{E P E N}^{5}\right)$, which point to a prison population with precarious access to education. Only $9.5 \%$ completed high school, while the national average is around $32 \%$ (DEPEN, 2019).

Most of the inmate population is comprised of young adults, with about $55.07 \%$ people up to 29 years old, out of which most of them are economically vulnerable and frequently (self) excluded from formal school, or never even had access to it. This leads to them having a lower educational level when compared to the national average (OLIVEIRA; JÚNIOR, 2018).

Joining the conversation, Xavier, Laurindo and Fialho (2018) state that a look at the sentence beyond its punitive character is of great relevance to ensure the psychological restructuring of the inmates, as well as the congruence with citizenship in the sense of harmoniously returning to the social environment. The sentence must fulfill its role of resocialization in a conscientious way so that the inmate understands the meaning of deprivation of liberty from which he will not be immune, but that he also understands the socialization process and, in common agreement, accepts to join it without being forced to.

To França, Félix and Feitosa (2020), the school within prisons aims to guarantee citizenship under the view of human rights, given that education is an essential right to liberty deprived people, which aims to include these subjects, since incarceration places them at an excluding dimension of the social system, making them a group that no longer carries their names, starting to be called simply prisoners.

\footnotetext{
${ }^{5}$ DEPEN: from the Portuguese Departamento

Penitenciário Nacional.
}

Also, according to the authors, these subjects lose their identities and, therefore, will need to recover them healthily to be returned to the heart of the society that discriminates them so much. Due to this bias, exclusion and inclusion are not similar concepts; they define and depend on the horizon from which one looks, the perspective we assume, our historical point of view (our society is marked by the contradiction between the real and the prescribed) and the appreciation of cultural expressions.

Educational actions promote pragmatic content and also seek to exert a constructive and transformative movement in the life of those deprived of liberty, fostering conditions for them to perceive themselves as individuals and social actors, capable of building their own life projects. Freire (2015) states that, when man understands his reality, he can hypothesize about the challenges and propose solutions to transform it, and, with his work, he can create a world of his own, with his self and his circumstances. This movement mobilizes skills and competences, building citizenship with pedagogical projects and educational activities that bring hope and dynamics to daily prison life, providing opportunities for the creativity of students through pedagogical practices, while also being an action to overcome idleness (MARTINS; SILVEIRA; COSTA, 2019).

According to these authors, the educational process is a mobilization strategy for the inmate population to try to reinsert themselves into society - a process that contributes to their formation as citizens. Thus, education offered within prisons should not be seen as a favor or as a privilege; on the contrary, it should be seen as a path of transformation, of hope and novel possibilities to life in community.

Torres, José and Santos (2021) state that the provision of regular education in prisons receives greater importance when it is directed towards full human development and its potential, valuing socially excluded groups. This view helps to effect citizenship, the construction of knowledge, values, attitudes and behaviors.

In this scenario, it is essential to constitute formations that enable dialogue and integration between teachers, inmates, prison officers and other professionals of the Prison System, so that, from these perspectives, they can pay due attention to the pedagogical aspects that involve issues related to methodologies and educational actions with the use of appropriate and suitable teaching material for the development of EJA in a prison context (SANT'ANNA, 2017).

There is an imagery conceived of liberty deprived people and, therefore, there is a need for integration between the 
different actors and sectors that work in prisons. It is from this relationship that the multiple speeches and voices of students represent their place of speech. For Sant'Anna (2107), there is a great abyss regarding public policies aimed at educational processes and continuing education of teachers who work in these prison contexts.

According to Xavier, Laurindo and Fialho (2018), good policies and laws are of no use if they are not effectively practiced. When education is not egalitarian, it denotes a failure in the educational process, leading to an outdated view that there is Education for the poor and Education for the rich. This is the case with education for liberty deprived people, where they do not always aim to prepare inmates to continue their studies, even though the relationship between prison and educational processes can create possibilities to re-establish mutual coexistence and improve the social conditions of inmates.

To break through this paradigm, Torres, José and Santos (2021) state that access to literacy for the person who is deprived of liberty is one of the ways to guarantee the rights of social inclusion and educational and intellectual development, still seen as a result of the act of teaching or of learning how to read and write.

In this sense, Freire (2001) points out that the act of reading should provide both the reading of the word and the critical reading of the world, based on historical, political and social conditions. Reading always implies a critical perception, interpretation and rewriting of what is read. In this sense, the literate person starts to have another social and cultural dimension, which is not only about upgrading their status or social, cultural class, but changing their social and cultural place, their way of living in society within this context and with cultural assets (TORRES; JOSÉ; SANTOS, 2021).

Thus, returning to the thoughts of Sant'Anna (2017), another possibility of education in prison can be strengthened by the training of professionals who work in these spaces, something that needs to occur continuously, since the educational practice in prisons regardless of its modality, requires a lot of creativity, dialogue and understanding.

As for the limits of carrying out educational practices in prison, it is essential to highlight that punishing and rehabilitating are the main objectives of our prison system; however, the imperatives of punishment end up overlapping with education, and this dual purpose expected from incarceration causes a lot of bias, denouncing contradictions in the organization of prisons. For Bessil and Merlo (2017), this has consequences, as the subject who returns to society is not always re-educated or re-socialized. It is clear that isolation from society and the violation of some rights neglects the opportunity for subjects to access educational processes and, consequently, leads them to losing the opportunity for change.

In prisons, there is usually an education for "domestication" marked by alienation from the rules that guarantee survival in the prison environment. It is, therefore, far from an education for "freedom", in its most human sense, as proposed by Freire (2008).

Sant'Anna (2017) points to the difficulties of specialized monitoring for teachers in this peculiarity of teaching and spaces, with an integrated training project. It also reflects on the security conditions and scope of the Law of Criminal Enforcement (LEP), prompting a reflection on the role of prison education.

Another notorious limit is society's negative view of prison education and the teaching activity within it, which affects the reality of schools behind bars. The prejudice against the education of liberty deprived subjects seems to be present in society's imagination, which has led people to not recognize that education is a right for everyone, as well as not realizing the importance it has for social transformation in life of these individuals.

In this context, Custodio and Nunes (2019) point out that society has nurtured a misguided look at the prison system, as if the subjects who are there should be perpetually incarcerated, displaying a cultural vision in society which believes that just confining people is enough to solve their problems. This idea seems to influence the conceptions and actions of those responsible for prison security, with regard to education in this scenario, thus agreeing with the remarks previously raised by Sann'Anna (2017).

Bessil and Merlo (2017), investigating the dynamics experienced by teachers with prison education, reveal that the act of teaching depends on the authorization and organization of the prison security. This statement justifies the perception of many teachers when expressing an idea of the lack of teaching autonomy in prison schools, as they have to adapt to what is required of them, without taking into account the context and the need identified with regard to the student and the teacher.

On the other hand, there are some prisons in which the big problem is the lack of technical, human and financial resources, which often makes the development of some activities unfeasible (LOPES; NICO, 2018).

Martins, Silveira and Costa (2019) state that, in prison, most students participating in the provision of education have a very critical level of education, as most cannot read and write, being at the most basic level of literacy, but enrolled in classes equivalent to the first years of elementary school (1st to 5 th year). The authors also point 
out that most of these inmates stopped going to school at a very early age, or never even attended it. Thus, throughout their lives, the consequence is the low level of education in the prison system.

This characteristic results in the difficulty presented by students who are in the literacy process regarding reading and interpreting texts. Those who are enrolled in other grades of Elementary School I have undeveloped writing, as well as delayed mathematical calculations. Other elements can be pointed out as limiting factors for the development of educational practices and contributing to learning difficulties, such as: poor diet, lack of supplies, drug users with great difficulty concentrating, lack of space in cells for school activities such as reading, for example (FRANCE; FÉLIX; FEITOSA, 2020).

The study by Bessil and Merlo (2017) portrays the physical and mental investment made by teachers to carry out their educational activities, as well as to deal with intercurrent situations that occur within prison units, making clear the differences between the work carried out by the teacher in a regular teaching network and the one carried out in prison institutions. This differentiation goes beyond the physical space, involving supply resources, methodological resources, prison routine, student turnover, recurrent absences, time for students to move to the classroom, among others.

In this approach, Forêncio and Costa (2021) emphasize that it is absurd that, in the name of the law, people have to be subjected to inhumane conditions, with no possibility of personal, cultural, and educational development or professional training and qualification. Worse yet, to also be submitted to sociability rules where there is a predominance of the logic of favors and benefits imposed by those who have power over others, including people's lives.

As the limiting reality of the interior of prisons becomes known, we can observe that there is a lack of an educational practice that is punctual and effective for the liberty deprived population. Therefore, it is necessary to develop an emancipatory pedagogy in the prison environment (OLIVEIRA; JÚNIOR, 2018).

In this aspect, we observe that education and teaching have their specificities when they unfold in the prison environment, as they are now subjected to a prison logic, that is, compliance with established rules and procedures. It is evident that education in prisons or places of restriction of freedom, as a right of the subject and a duty of the State, should be an important topic for debate, as it constitutes a current challenge to be faced by different groups of society.

\section{FINAL THOUGHTS}

The right to education is one that is legally preconized, achieved by the promulgation of several national and international documents. Within an EJA perspective for liberty deprived peoples, on the other hand, it presents itself as a primordial factor in the conduction of resocialization processes, being considered an essential part of Basic Education aimed at a specific clientele, so that it has its specificities and peculiarities that must be seen under the prism of the individual's emancipation and autonomy.

EJA for the convicts must be thought in the sense of amplifying the pedagogical qualification regarding educational practices, within the aspects of a popular education starting from the culture, history and experiences of the subjects as the driving force of the political educational principle, where the individual is considered as the subject of their own history.

To think, in this sense, is to promote infrastructure conditions and pedagogical practices to meet the specific needs of this audience. Well, the infrastructure of Brazilian prisons contains cells that are not adapted for classrooms. Throughout its history, the construction and implementation of classrooms were not designed for subjects who need spaces and conditions for reflection and learning, as well as pedagogical practices, do not encourage dialogue and a liberating pedagogy, based on popular education, which seeks the emancipation of the individual and their re-socialization.

Given the scenario presented here, it is worth noting that the school teachers in prison face numerous challenges in their teaching activities. Challenges, that are related to the disinterest of a society that has an influential view of prison schools due to the lack of autonomy of teachers, the lack of support from the school, the non-recognition of the importance of education by other professionals and, mainly, the precariousness of its physical structure.

Even in the face of such precariousness, the institutional school that works in prisons cannot limit itself exclusively to transmitting content and enabling social mobility. It must challenge the actors involved to go even further, creating possibilities for prisoners to have new opportunities, developing survival strategies without depersonalization of the subject, and that can reintegrate them or reinsert them into social life, with chances of repeat offenses.

The training of professionals who work in these spaces, especially teachers, needs to take place in a truly continuous way, as the public involved is undergoing precautionary measures and/or are those legally deprived 
of their liberty, needing to build a learning based on creativity, dialogue and on social respect.

It becomes essential for EJA teachers in private prisons to understand that there are formed and distorted images about people and coexistence in these places, thus justifying a real need for interaction between different subjects and social sectors that work in prisons. This relationship will develop educational possibilities under a perspective of collective organization, which agrees with the multiplicity of speeches that reside and occupy this space, representing cultural nuances that bring the free society and the incarcerated society closer.

Moreover, it is essential to highlight that the high student turnover makes it impossible for them to advance further in terms of content. This causes anguish and suffering for teachers. The way in which the security team is organized is also highlighted in studies, as the teachers sometimes feel safe by the presence of these professionals, but sometimes they feel trapped with not having the autonomy to carry out some activities/dynamics that would make the classes more attractive, such as supplies or audiovisual resources, for example.

As a limitation for the development of educational practices in prisons, the precariousness of the pedagogical spaces in which classes are held is notorious, as well as the mask of the social stigma that many teachers carry when they are socially frowned upon for teaching in these places. It is essential that formations are created that enable dialogue and integration between teachers, inmates, prison officers and other professionals in the Prison System, in compliance with pedagogical aspects and educational activities in these spaces.

Therefore, we can perceive that public policies, with regard to LDP education, still hurt people's rights and urgently require the resumption of a demystifying dialogue that takes prison education beyond human rights. It should be emancipatory and liberating, guiding the subject to retake their place as social actors so as not to perpetuate the cycle of alienation and accommodation of the subject in a situation of deprivation of liberty.

\section{REFERENCES}

[1] BESSIL, Marcela Haupt; MERLO, Álvaro Roberto Crespo. A Prática Docente de Educação de Jovens e Adultos no Sistema Prisional. Psicol. Esc. Educ., Maringá, v.21, n. 2, p. 285-293, Aug. 2017 . Available in: http://www.scielo.br/scielo.php?script=sci_arttext\&pid=S1 41385572017000200285\& ng=en\&nrm=iso. Access in: 21 May 2021.
[2] BOGDAN, Robert; BILKEN, Sari. Investigação qualitativa em educação. Uma introdução à teoria e aos métodos. Porto: Porto Editora, 1994

[3] BRASIL. Constituição (1988). Constituição da República Federativa do Brasil. Brasília, DF: Senado Federal: Centro Gráfico, 1988.

[4] __ Lei de Execução Penal (LEP): Lei 7.210, de 11 de julho de $1984 . \quad$ Available in: http://www.planalto.gov.br/ccivil_03/Leis/17210.htm. Access in: 05 May 2021.

[5] ___ Lei $\mathrm{n}^{\circ} 9.394$, de 20 de dezembro de 1996. Estabelece as Diretrizes e Bases da Educação Nacional. Brasília. 1996. Available in:

[6] http://www.planalto.gov.br/ccivil_03/Leis/19394.htm. Access in: 20 Apr. 2021.

[7] __ Lei Federal 13.005, de 25 de junho de 2014. Aprova o Plano Nacional de Educação - PNE e dá outras providências. Brasília, DF, 25. Jun. 2014. Available in: < http://www.planalto.gov.br/ccivil_03/_ato2011-

2014/2014/lei/113005.htm>. Access in: 17 May 2021. 2001. (Coleção questões de nossa época, v. 23).

[8] _ Ministério de Educação e Cultura. Conselho Nacional de Educação. Parecer $n^{\circ}$ 04, de 9 de março de 2010. Diretrizes Nacionais para a Oferta de Educação para Jovens e Adultos em Situação de Privação de Liberdade. Brasília, 2010.

[9] CARNEIRO, Moacir Alves. LDB fácil: leitura critico compreensiva, artigo a artigo. 19. Ed.Pedtropolis, RJ: Vozes, 2012.

[10] CUSTODIO, Glauber Cesar Cruz. NUNES, Célia Maria Fernandes. A Docência em "celas de aula": Desafios dos professores de educação física em escolas prisionais. Reflexão e Ação. Santa Cruz do Sul, v. 27, n. 2, p. 130-147, mai./ago. 2019. Available in: https://www.researchgate.net/publication/335156993_A_do cencia_em_celas_de_aula_desafios_dos_professores_de_ed ucacao_fisica_em_escolas_prisionais. Access in: 01 May 2021.

[11] DEPARTAMENTO PENITENCIÁRIO NACIONAL (DEPEN). Levantamento Nacional de Informações Penitenciárias: INFOPEN - Dezembro de 2019. Available in:

https://app.powerbi.com/view?r=eyJrIjoiMTVjZDQyODUt $\mathrm{N} 2 \mathrm{FjMi0}$

0ZjFkLTlhZmItNzQ4YzYwNGMxZjQzIiwidCI6ImViMD kwNDIwLTQ0N GMtNDNmNy05MWYyLTRiOGRhNmJmZThlMSJ9.

[12] FLORÊNCIO, Roberto Remígio. COSTA, Ênio Silva da Costa. A escola no Cárcere: Uma reflexão sobre a educação dentro dos presídios brasileiros. Revista Educação em Debate. v.43, n.81, Fortaleza, p.27-37 jan-abr 2021. Available http://www.periodicosfaced.ufc.br/index.php/educacaoemd ebate/article/view/1121. Access in: 05 May 2021.

[13] FRANÇA, Rosangela de Fátima Cavalcante. FÉLIX, Atalia Serra. FEITOSA, Débora Ferreira da Silva. A EJA e as dificuldades de aprendizagem dos alunos: Implicaçãos encontradas no sistema prisional. Humanidades e Inovação. 
v.7, n.15, Palmas, p.383-392 jun 2020. Available in: https://revista.unitins.br/index.php/humanidadeseinovacao/ article/view/2965. Access in: 10 May 2021.

[14] FREIRE, P. Educação como prática da liberdade. 31. ed. Rio de Janeiro: Paz e Terra, 2008.

[15] __ Paulo. Política e educação: questões da nossa época. 5. ed. São Paulo: Cortez.

[16] GADOTTI, Moacir. Educação de Adultos como Direito Humano EJA em Debate. Florianópolis, Ano 2, n. 2. Jul. 2013. Available in: https://periodicos.ifsc.edu.br/index.php/EJA/article/view/10 04/pdf. Access in: 05 May 2021.

[17] GADOTTI, Moacir; ROMÃO, José E. Educação de Jovens e Adultos: teoria, práticas e propostas. $4^{\circ}$ Ed. São Paulo: Cortez: Instituto Paulo Freire, 2001.

[18] LOPES, Nádia. NICO, Bravo. A Educação nos estabelecimentos prisionais. Repositório da Universidade de Évora. Dez. 2020. Available in: https://dspace.uevora.pt/rdpc/bitstream/10174/29245/1/BN. CL.53.pdf. Access in: 05 May 2021.

[19] MARTINS, Elcimar Simão. SILVEIRA, Ana Lúcia Nobre. COSTA, Elisangela André da Silva. Educação de Jovens e Adultos no contexto prisional: Limites e possibilidades no Maciço de Baturité/CE. Revista Expressão Católica. v. 8, n. 1; Jan - Jun, p.5-16; 2019. Available in: http://publicacoesacademicas.unicatolicaquixada.edu.br/ind ex.php/rec/article/view/3260. Access in: 07 May 2021.

[20] MINAYO, M. C. S. Análise qualitativa: teoria, passos e fidedignidade. Ciência Saúde Coletiva. v.17, n.3, p.621-626, 2012.

[21] OLIVEIRA, Andreza Márcia Viana. JÚNIOR, Ebenezer da Silva Melo. A educação de jovens e adultos em situação de Privação de liberdade: Perspectivas e apontamentos. Revista Formação @Docente-Belo Horizonte. V.10, n.2 2018. Available in: https://www.metodista.br/revistas/revistasizabela/index.php/fdc/article/view/1440. Access in: 03 May 2021.

[22] SANT' ANNA, Sita Mara Lopes. Perspectivas da educação de jovens e adultos no sistema prisional. Diálogo, Canoas, n. 35, p. 37-44, ago. 2017. Available in: https://revistas.unilasalle.edu.br/index.php/Dialogo/article/v iew/3259. Access in: 05 May 2021.

[23] TORRES, E. N. da S., JOSÉ, G. de O. M., \& Santos, M. B. dos. (2021). Vozes do cárcere: A prática literária e a redução de pena pela leitura na perspectiva de pessoas privadas de liberdade. Plurais Revista Multidisciplinar, 6(1), 92-115. Disponível em :https://doi.org/10.29378/plurais.24479373.2021.v6.n1.10230. Access in: 05 May 2021.

[24] XAVIER, Antonio Roberto. LAURINDO, Wedyla Silva. FIALHO, Lia Machado Fiuza. Legislação Educacional para o cárcere. Cadernos de Educação. v. n.60, p.75-97, juldez.2018. Available in: https://periodicos.ufpel.edu.br/ojs2/index.php/caduc/article/ view/11388. Access in: 05 May 2021. 